\title{
Using the Law: Working-Class Communities and Carnal Knowledge Cases in Victoria, 1900-06
}

\author{
Jennifer Anderson
}

The case, $R v$ Gravino, which came before the Supreme Court of Victoria in 1905 , illustrates well the complex debates which often preceded state involvement in sexual assault cases and are revealing about community decisions to engage with the legal system. On 7 March 1905, 14-year-old Elsie Griffiths disclosed to her mother that their neighbour, 17-year-old Charlie Gravino, had sexually assaulted her or, in her words, 'had me down at his place doing rude things'. Elsie's father was dead, and her mother, Catherine Griffiths, kept a laundry in the Melbourne suburb of Brunswick, behind which Elsie lived with her mother, her 11-year-old brother Albert and her adult sister, Kate. The previous evening, Elsie had been sent out to look for her brother, when she met Charlie at the end of the lane. The two went into Charlie's house, calling out for Albert. There, apparently taking advantage of no one being home, Charlie pushed Elsie down onto the ground and attempted to rape her. ${ }^{1}$ On the evening of 7 March, Catherine took Elsie to Charlie's house, where they spoke to Charlie in front of his mother and stepfather. Catherine asked Charlie whether he had assaulted Elsie and he eventually admitted that 'he might have done'. At that point, according to Catherine, Charlie's mother 'asked me to forgive the boy' and she and Charlie shook hands. Catherine was prepared to forgive Charlie, she told the court, because 'no harm ha[d] been done to her [Elsie]. I said this because she wasn't monthly, she was too young' ${ }^{2}$ This outcome, however, did not satisfy Elsie's elder sister Kate, who evidently held a different opinion as to what constituted 'harm'. The next day, Kate took matters into her own hands and demanded a written apology from Charlie, 'for satisfaction for my sister's character'. When no letter was forthcoming, Kate took Elsie to the police and then the hospital. After the medical examination, Charlie was charged with the attempted carnal knowledge of Elsie Griffiths. ${ }^{3}$

\footnotetext{
1 Statement of Elsie Griffiths, $R v$ Charles Gravino, Melbourne Supreme Court, 23 May 1905, Public Record Office Victoria (PROV), VA 667 Office of the Crown Solicitor, VPRS 30/P/0000 Criminal Trial Briefs, Unit 1385, Item 163. Charles was charged with attempted carnal knowledge because there was no medical evidence of actual penetration. He was convicted of indecent assault, see commentary in 'Criminal Court', Age (Melbourne), 26 May 1905, 10.

2 By which she meant that Elsie had not yet started menstruating, statement of Catherine Griffiths, ibid.

3 Statement of Kate Griffiths, ibid.
} 
In some ways, Gravino was an atypical carnal knowledge case to come to the attention of the Melbourne police in 1905. Siblings rarely intervened to the extent that Kate Griffiths did and, without her involvement, the matter probably would have gone no further. Like the families in Gravino, many parties in such cases were working class and, while these discussions were critical to the participants, they have attracted little academic attention. Since the 1980s, there has been a significant amount of feminist historical and legal scholarship on sexual crimes, with two main areas of interest. One strand of inquiry has examined the development and enforcement of legislation prohibiting underage sexual activity. Scholars have argued that middle-class reformers, including feminists, child rescue workers and social purists, advocated more stringent definitions of permissible sexual conduct from the 1870s and 1880s, as part of a drive both to delineate childhood and to control adult male sexuality. ${ }^{4}$ The same literature has suggested that the regulatory attempt was thwarted, at least in part, by ambivalent attitudes towards female sexuality in law. ${ }^{5} \mathrm{~A}$ second, albeit overlapping, strand has focused on court proceedings, exploring the influence of contemporary attitudes to gender, morality, class and race on the outcomes of prosecutions and on legal rules and practice. ${ }^{6}$ Such scholarship has often been overtly present centred, tracking historical precedents for the continuing problems women face in prosecuting sexual offences, and lending support to campaigns to alter rules of evidence and court practice. ${ }^{7}$ It has also offered explanations for why so few matters progressed to trial and for low conviction rates. $^{8}$

Yet, before the legal process was engaged, offending behaviour had first to come to the attention of the authorities. If we assume, then as now, that most young women, or their families, did not make their experiences of sexual offences against them public, ${ }^{9}$ studying the circumstances of those who did opens up

4 In Australia see Jill Bavin-Mizzi, Ravished: Sexual Violence in Victorian Australia (Sydney: University of New South Wales Press, 1995), 14; Bavin-Mizzi, 'Understandings of Justice: Australian Rape and Carnal Knowledge Cases, 1876-1924', in Sex, Power and Justice: Historical Perspectives of Law in Australia, ed., Diane Kirkby (Melbourne: Oxford University Press, 1995), 19-20. In the United Kingdom see Lucy Bland, Banishing the Beast: English Feminism and Sexual Morality, 1885-1914 (Harmondsworth: Penguin, 1995), xiiixvii, 97, 110-12, 122-23; Louise A. Jackson, Child Sexual Abuse in Victorian England (London and New York: Routledge, 2000), 1-6, 12-17. In the United States, see Mary E. Odem, Delinquent Daughters: Protecting and Policing Adolescent Female Sexuality in the United States, 1885-1920 (Chapel Hill and London: University of North Carolina Press, 1995), 1-7, 9-10.

5 Jackson, 3-4; Odem, 64, 71-72; Bavin-Mizzi, Ravished, 42, 83-84; Constance Backhouse, 'Skewing the Credibility of Women: A Reappraisal of Corroboration in Australian Legal History', Western Australian Law Review 29 (2000): 29, 79-107.

6 Odem, 64-81; Bavin-Mizzi, Ravished, 10-13, 42-67, 83-87. See also Judith Allen's classic Sex and Secrets: Crimes Involving Australian Women Since 1880 (Melbourne: Oxford University Press, 1990), 57-62, which outlined the difficulties facing both rape and carnal knowledge victims in prosecuting cases successfully.

7 Allen, 2, 14, 252, 255; Backhouse, 80-81.

8 Bavin-Mizzi, Ravished, 197-203.

9 The general belief is that sexual offending against women and children, in Australia and elsewhere, has always been significantly under-reported. See Allen, 9-10; Jackson, 25-26. 
alternative, and equally interesting, lines of inquiry. Which groups tended to appear before the courts and what triggered the decision to notify the police? What did parties feel they had to gain, or lose, by legal involvement? Did they have any preliminary understanding of the legal process, which might affect their decision to make a complaint or to stay silent? Given the strong workingclass presence in this jurisdiction, such questions also invite us to consider the extent to which such communities were agents in these proceedings, or whether they were more often the subjects of state intervention. To date there have been no Australian studies on this point, although scholars in the United Kingdom and United States have considered similar questions. Louise Jackson's study of child sexual abuse in Victorian England argued that working-class populations had informal as well as formal methods of dealing with sexual offending, with cases more likely to be reported if they involved non-family members. Incest in particular was likely to be hidden. ${ }^{10}$ She suggested that the police were not the automatic resort for such communities as relationships with authority were often fractured, although she also contended that they still viewed the law as the 'appropriate final resolution' ${ }^{11}$ By contrast, Mary Odem's work on statutory rape cases in the Californian courts in the 1910s indicated that working-class, and particularly immigrant parents, used age of consent legislation to try and control daughters whose sexual relationships flouted familial and community expectations. ${ }^{12}$

The varying conclusions in these works can be explained in part by the different subjects of the studies, as well as the differences of time and place. Jackson was examining non-consensual sexual activity, or the rape of (mostly) young children. Odem focused on older girls who were more likely to be engaging in consensual sexual relationships. 'Carnal knowledge' cases, of course, covered the spectrum, from the forcible abuse of small girls to adolescent relationships. Nevertheless, given the lack of Australian research on this point, it is worthwhile to start by examining the available cases more generally, to see whether patterns that have been identified in British and American sources also held here. My primary source was the records of carnal knowledge proceedings listed in the Melbourne Supreme Court between 1900 and 1906. The majority of the matters came from the city of Melbourne, but the jurisdiction of the court also encompassed country areas where the court did not travel on circuit, so allowing for exploration of a mix of urban and rural cases. Most of the transcripts for these cases have survived and offer a rich source for the views of the witnesses who appeared before the courts. My approach was strongly influenced by the work of historians like Mark Peel, who have argued that we should heed the 'real voices' of working-class communities, the subjects of intervention, as

10 Jackson, 31, 47-48.

11 ibid., 36-40.

12 Odem, 40-47. 
much as the regulators whose views have so often dominated..$^{13}$ Documenting in their own words' why people chose to use the law, in this particularly emotive and difficult area, throws important illuminations on attitudes towards sexual offending, the law and the reach of the regulatory state in Australia in our period.

The first part of the chapter outlines the legislative background and the sources used in the study. The second and third parts explore who reported sexual offending to the police, beginning with the circumstances in which state agents were involved from the outset, before turning to the more common scenarios in which family members made the decision to engage with the legal system. The fourth considers the expectations that families seem to have brought to court and, by outlining the outcomes in these cases, suggests that expectation and reality were often sharply divergent. I conclude by summarising the circumstances in which working-class communities in Victoria at this time used the law to regulate sexual conduct and what was distinctive about their choices.

\section{Jurisdiction and sources}

The offence of carnal knowledge of a girl under the age of 16 was created in the colony of Victoria by the Crimes Act 1891, which raised the age of consent from 12 to 16. This Act replaced in part the Crimes Act 1890, itself simply a restatement of earlier legislation. The 1890 Act had contained two such offences. Carnal knowledge of a girl under 10 was a capital offence. Carnal knowledge of a girl between 10 and 12 was a misdemeanour, punishable by a term of imprisonment. ${ }^{14}$ The new Act left the capital offence alone, but established an overarching felony of 'carnal knowledge of a girl between 10 and 16', punishable by a maximum of 10-years imprisonment. If the defendant was the girl's teacher, the maximum sentence was 15-years imprisonment. ${ }^{15}$ The Act also created associated charges of attempted carnal knowledge and assault with intent to carnally know, misdemeanours punishable by three years imprisonment (five if the defendant was the girl's teacher). ${ }^{16}$ Consent was no defence to either charge unless the girl was the same age or older than the defendant, a requirement the Victorian Supreme Court interpreted very strictly. ${ }^{17}$ The 1891 Act was modelled closely on the 1885 English Criminal Law Amendment Act and, like that Act, was the result of extensive campaigning by women's groups, social purists,

\footnotetext{
13 Mark Peel, The Lowest Rung: Voices of Australian Poverty (Cambridge University Press, 2003), 11-15.

14 Crimes Act 1890 (Vic), ss. 45 and 47.

15 Crimes Act 1891 (Vic), s. 5(1).

16 ibid., s. 5(2).

17 ibid., s. 6. In $R v$ Hibbert 1906 Victorian Law Reports at 198 Hodges J held that 'the same age or younger' should be interpreted as 'born on the same day or younger'.
} 
clergy and charitable organisations, who had argued that the existing legal framework left young girls vulnerable to sexual exploitation. ${ }^{18}$ Nevertheless, there were also significant differences. Unlike the English Act, the Victorian version contained no defence of reasonable belief that the girl was over $16,{ }^{19}$ and allowed a more generous time frame for prosecution. ${ }^{20}$ The 1891 Act also created a new offence of incest, or carnal knowledge of a daughter, lineal female descendant or stepdaughter, an offence not limited by the girl's age. ${ }^{21}$

Carnal knowledge charges were heard before judge and jury in the Supreme Court. The trial was preceded by a committal, or preliminary, proceeding in the local police court, presided over by a bench of magistrates. Between 1900 and 1906, 70 carnal knowledge and related cases were listed for hearing in the Melbourne Supreme Court: of these, 69 actually proceeded to trial. These cases were a small number of the total listings - there were between seven and 14 each year, out of a total of between 500-600 cases overall. In the absence of exact records we can only speculate as to how many matters did not make it past committal although, from newspaper reports and contemporary commentaries, it would seem that there was a fair rate of attrition at the police court stage. ${ }^{22}$ Of those that did advance to the higher court, 30, or 43 per cent, ended in acquittal. In 26 cases ( 37 per cent) defendants were convicted of the principal charge in the Crown indictment and, in 4 matters ( 6 per cent), the defendant was convicted of a lesser charge. Seven defendants (10 per cent) pleaded guilty, and one pleaded guilty to a lesser charge. In two cases the prosecution ultimately entered a nolle prosequi, in one case before trial because the defendant had died and in the other after two trials where the jury disagreed. Rates of conviction, however, varied significantly from year to year, from a low of 25 per cent in 1906, to a high of 71 per cent in 1903, with no definitive pattern except that the acquittal rate increased slightly in years with higher numbers of cases.

Where a carnal knowledge case was listed for hearing in the Melbourne Supreme Court, the Victorian Crown Prosecution Office prepared a brief of evidence

18 Women's Christian Temperance Union of Victoria, Fourth Annual Report during the Year 1891 (Melbourne: Peacock Bros. Printers, 1892), 4-5; 'The Protection of Girls - Deputation of Clergymen to the Premier', Age (Melbourne), 19 August 1891, 5; 'Protection of Young Girls', Age (Melbourne), 14 November 1891, 4.

19 Criminal Law Amendment Act 1885, 48 \& 49 Vict c. 69, s. 5.

20 The Criminal Law Amendment Act 1885 initially limited prosecution to within three months of the commission of the offence, see s, 5. The 1891 Victorian Act (s, 7) allowed 12 months.

21 Crimes Act 1891 (Vic) s. 8.

22 In the 1890s the Victorian Women's Christian Temperance Union had launched a high-profile campaign to increase the numbers of defendants who were committed for trial, see Women's Christian Temperance Union, Eighth Annual Report during the Year 1895 (Melbourne: Spectator Publishing Co, 1896), 12, 46-47. Feminist commentators continued to criticise the operation of the committal system into the twentieth century, see, for example, the remarks in the journal Woman's Sphere (edited by the prominent feminist and suffrage campaigner Vida Goldstein), 'General Comments', vol. I, no. 9, May 1901, 73-74; 'Letter to the Editor', vol. I, no. 12, August 1901, 99; 'Children's Courts and Police Matrons', vol. II, no. 18, 10 February 1902, 145; 'Comments', vol. III, no. 34, 10 June 1903, 306. 
which contained typed transcripts of the evidence given by the witnesses at the committal hearing and the other documents on which the Crown relied to make out its case. These generally included the girl's birth certificate, the complaint and warrant, statements from expert witnesses, subpoenas and bail documents, and occasionally other legal correspondence. The brief sometimes also included letters between a girl or her family members and the defendant, if this material was seen to assist the case. The transcripts were evidently mediated by the questions asked and, to some extent, they were overlaid with legal language. ${ }^{23}$ When combined with these additional records, however, they allow us to piece together a reasonably accurate picture of the relationship between complainants and defendants, the social standing of the parties and how the matter came to the attention of the police.

In the overwhelming majority of carnal knowledge cases the parties knew each other, often well. I accessed the prosecution briefs for 68 of the 70 cases listed for trial between 1900 and $1906,{ }^{24}$ and divided the relationships in these cases into five broad categories. The first was members of the same household, which included both family members and non-relatives, such as fellow employees (20 cases, or 28 per cent). The second (also 20 cases) included non-resident family members, friends and neighbours. In nine cases (12.6 per cent) complainant and defendant identified themselves as boyfriend and girlfriend. The fourth category I called 'acquaintances', which I used to describe situations in which the parties knew each other slightly, even if they had only met on the day of the incident (12, or 17.6 per cent). In only six cases were the defendants total strangers ( 9 per cent). One matter fell outside these categories, where the defendant was the girl's former teacher.

The ages of the girls involved varied from 16 months to 21 years, although there was a significantly larger number of older complainants, or girls who had passed through puberty. Specifically, there were six children under 10 at the time of the offence ( 8.4 per cent) and 10 (14 per cent) aged between 10 and 12 . Thirteen girls were 13 years old (18 per cent), 17 girls were 14 (24 per cent), 21 were 15 (29.5 per cent), 2 were 16 ( 3 per cent), one was 17 and one $21 .^{25}$ Three of the four girls over 16 were complainants in incest charges and the 17-year-old the (reluctant) complainant in a charge of abduction with intent to carnally know, where the age of consent under the 1891 Act was $18 .{ }^{26}$ Most of the younger children were old enough to be deemed capable of giving sworn evidence, a factor important to magistrates when they decided to allow a case to proceed to trial.

23 The witnesses, for example, invariably refer to the defendant as 'the accused', 'the defendant' or 'prisoner' and, in some cases, it is clear that a child's evidence has been doctored to make it flow more logically. In other circumstances, however, the transcript is apparently very literal, including witnesses' grammatical errors, contemporary turns of phrase and slang.

24 One brief was missing and one was unable to be ordered.

25 There were in total 72 complainants, as three cases involved two complainants each. 
Of the 68 cases, 44 (64.7 per cent) came from the city of Melbourne, with the remaining 24 from a variety of country areas. The numbers reflected the court's jurisdiction as well as the greater population concentration in Melbourne. The Victorian Supreme Court travelled on circuit to larger country towns, so the rural cases which made their way to Melbourne were usually from areas closer to Melbourne than other regional centres. A number of matters, for example, came from the foothills of the Dandenongs and four cases were from the seaside town of Sorrento, 112 kilometres south of Melbourne. The overwhelming majority of complainants and defendants, from both urban and rural areas, were working class. I assessed the parties' class on the basis of where they lived, how they described their living arrangements, their occupation if they had one, and their parents' occupations. Of the 44 cases from Melbourne city, in all but five cases, the parties lived in extensively working-class areas, from the southern suburbs of South and Port Melbourne to Footscray in the west and North Melbourne, Carlton, Collingwood, and Fitzroy in the inner north and east. The only complainant who resided in a definitely middle-class area (Armadale in the southeast) was a domestic servant living in her employer's house. Where complainants worked, they were employed mostly as domestic servants or in factories. Defendants recorded a variety of occupations, both skilled and unskilled. Most of the girls, though, did come from fairly solid middle or upper working-class backgrounds. Only eight of the 68 cases involved girls from very impoverished, or fringe-dwelling families, including one current and one former state ward.

\section{Case studies (1): State agents and professionals}

Proceedings in the carnal knowledge jurisdiction began with the signing of a formal complaint before a police officer or magistrate. Signing the complaint was usually the responsibility of a family member. Police prosecuted on their own initiative in only four of these cases. Where police were involved from the outset, there was invariably an additional public order issue, often of suspected juvenile prostitution. In $R v$ Kelly, ${ }^{27}$ for example, Constable Edward Monkivitch was on duty outside the Exhibition Gardens in Carlton in May 1906, when he observed John Kelly behaving suspiciously towards 13-year-old Elsie Lawson. He followed the two and caught Kelly about to have intercourse with Elsie under a tree. At the police station, Elsie disclosed that Kelly had said he would give her sixpence if she went with him and that she had met him the Saturday before,

27 Melbourne Supreme Court, 15 May 1906, PROV, VPRS 30/P/0000, Unit 1421, Item 214. 
when he had given her a shilling. ${ }^{28}$ Police members who intervened in such situations seem to have been both particularly observant and committed to the cause. In $R v$ Martin, ${ }^{29}$ Constable Henry Grisfield apprehended 11-year-old Sarah Lawton and 12-year-old Gertrude Bigwood in Bourke Street, Melbourne, as they were being led away by a man. He took the girls to the station and obtained statements that also implicated Edward Martin, a Collingwood bootmaker. Grisfield then undertook an extensive investigation into Martin's behaviour, which ended in a successful prosecution for carnal knowledge of Sarah. Grisfield simultaneously charged both girls with neglect and asked that they be committed to the Industrial Schools. The jury in Martin's trial commended Grisfield for 'taking young girls off the streets'. ${ }^{30}$

Active police members were also sometimes instrumental in persuading family members to make a complaint against a defendant, particularly when they viewed conduct as infringing public order as well as private morality. Constable John Brophy had been keeping an eye on 15-year-old Alice Saunders, an orphan in service at Moonee Ponds, for some time, as he had 'heard that it was common talk amongst the boys that this girl was "good enough"'. ${ }^{31}$ When he discovered that she had become intimate with 17-year-old Charles Wilson, he interviewed her and accused her of the affair, which she denied. Brophy then wrote to her older brother, Herbert Saunders, who was living on Phillip Island, outlining the situation and advising him to come to Melbourne at once. Herbert came to town and, between them, they managed to get Alice to make a statement against Charles. Brophy then took Herbert Saunders before the city magistrate to obtain a warrant for Charles's arrest in October $1906 .{ }^{32}$ Police were also closely involved in the investigation of a sailor, William Doyle, for the carnal knowledge of 13-year-old Daisy Hamilton in January 1902. Daisy, also an orphan, lived with her older brother and sister in the port suburb of Williamstown. When she did not return home on the night of 18 January, her brother Walter reported her missing. Senior Constable Norgate saw her the next morning and asked her where she had been. She told him she had slept in a paddock, but he threatened her with the reformatory if she did not tell the truth. The next day he went to the pier and, seeing Daisy with Doyle, launched an inquiry that ended in Doyle's conviction for carnal knowledge. ${ }^{33}$

\footnotetext{
28 Statement of Elsie Lawson, ibid.

29 Melbourne Supreme Court, 15 February 1904, PROV, VPRS 30/P/0000, Unit 1348, Item 68.

30 'Criminal Court', Age (Melbourne), 29 February 1904, 9, and 'Police Intelligence', 3 March 1904, 9.

31 Statement of John O'Connell Brophy, $R v$ Charles Wilson, Melbourne Supreme Court, 15 November 1906, PROV, VPRS 30/P/0000, Unit 1434, Item 442.

32 Statements of Herbert Saunders and John O'Connell Brophy, ibid. Charles was convicted of attempted carnal knowledge, although the court remarked that the evidence showed 'evidence of revolting immorality amongst a number of boys and girls', see 'Criminal Court', Age (Melbourne), 22 November 1906, 10.

33 Statements of Daisy Hamilton and Henry Norgate, $R v$ William Doyle, Melbourne Supreme Court, 17 February 1902, PROV, VPRS 30/P/0000, Unit 1280, Item 122.
} 
Other state agents and professionals occasionally reported carnal knowledge cases to the police. When they acted, the girl had invariably been committed to their care and they were standing permanently or temporarily in place of her family. The Victorian Department of Neglected Children had the formal guardianship of all state wards until they turned 18, and sometimes beyond, ${ }^{34}$ but a departmental officer instigated the complaints system in only two of these matters. William Buswell notified the police in March 1901 after 15-year-old Margaret Green became pregnant, apparently to her employer's son, William Orr. Margaret had been a state ward since infancy and was licensed to Mrs Orr under an agreement with the department. ${ }^{35}$ In $R v O^{\prime}$ Gallaghan a nurse at the Industrial Schools depot alerted the authorities after nine-year-old Sylvia Derrick disclosed a sexual assault by her mother's de facto husband, Eugene O'Gallaghan, from whom she had contracted syphilis. Sylvia had recently been removed from her mother's care following allegations of neglect. ${ }^{36}$ In two other cases, refuge workers apparently persuaded girls to make formal statements about sexual misconduct. In 1902, Louisa and Lydia Ward, aged 21 and 17 respectively, disclosed to Mrs Pittman, manager of the Girls' Rescue Home in Armadale, that their father had sexually abused them for many years, resulting in Louisa's pregnancy. ${ }^{37}$ In 1906, 16-year-old Bessie Martin made a statement to the Carlton Refuge Committee that a family friend, Francis Hendry, had assaulted her earlier that year. Bessie came to live in the refuge six months later and only then made a complaint. ${ }^{38}$

As the intervention of the refuge workers suggests, professionals, like the police, might also influence complainants or their family to report sexual offending, even if they did not personally notify the authorities. No doctor, for example, actually reported a suspected carnal knowledge offence, at least amongst these cases. In several incidents, however, their recommendations assisted family members to make an obviously difficult decision. In one particularly serious case, $R v$ Thomas Brown, ${ }^{39}$ from August 1900, Alice Anderson knew that her 16-month-old baby girl Etta had been sexually assaulted and suspected their neighbour, Thomas Brown, who had been in the shed with Etta just before she returned to the house bruised and bleeding. Despite Etta's age, Alice revealed the assault to no one except her husband Albert for two weeks, explaining that she 'did not want to make it public for the child's sake'. ${ }^{40}$ Two weeks later,

\footnotetext{
34 Neglected Children's Act 1890 (Vic) s. 25.

35 Statements of William Buswell and Margaret Green, $R v$ William Orr, Melbourne Supreme Court, 15 April 1901, PROV, VPRS 30/P/0000, Unit 1238, Item 18.

$36 R$ v Eugene O'Gallaghan, Melbourne Supreme Court, 15 November 1901, PROV VPRS 30/P/0000, Unit 1268 , Item 489.

$37 \quad R v$ John Ward, Melbourne Supreme Court, 15 April 1902, PROV, VPRS 30/P/0000, Unit 1287, Item 223.

$38 R v$ Francis Hendry, Melbourne Supreme Court, 12 December 1906, PROV, VPRS 30/P/0000, Unit 1438, Item 495.

39 Melbourne Supreme Court, 15 August 1900, PROV, VPRS 30/P/0000, Unit 1223, Item 335.

40 Statement of Alice Anderson, ibid.
} 
when Etta still had a discharge, which did not seem to be improving, Alice took her to Dr Strahan who found that the baby had definitely been assaulted and 'told the mother to inform the police'. ${ }^{41}$ Alice and Albert still prevaricated for a time, Albert telling the court that 'I had no money and ... I was afraid that the man might injure me'. ${ }^{42}$ Eventually, though, they did go to the police. Similarly, Victoria Ginn gave birth to a baby boy in July 1900, when she was 17 . The child was her father's, although Victoria told her family at the time that she had had a liaison with a married man. In late 1901 she took the baby to the Children's Hospital where the doctor apparently diagnosed congenital syphilis and told Victoria that the child's father should be publicly exposed and punished. ${ }^{43}$ Victoria then made a complaint against her father.

\section{Case studies (2): Family, friends and complainants}

By far the more usual scenario, though, was that in which a member of the girl's family notified the police. In 50 out of 68 cases (73.5 per cent) a relative, mostly a parent, reported the offence. This decision was rarely an easy one. It often occurred only after extensive efforts to negotiate a settlement, financial or otherwise, out of court. Patterns of negotiations reflected power relations within families and communities. If available, and not the defendant, fathers usually filed the complaint, and they were also expected to take a leading role in negotiations. In $R v$ Leftley, ${ }^{44}$ a typical example, 15-year-old Blanche Howes had been in a sexual relationship with, and became pregnant to, 19-year-old Harry Leftley. After Blanche sought medical advice about the pregnancy, the doctor told her mother, Mary. Mary informed her husband, Frederick, who, unusually, sought legal advice. The solicitor presumably advised him to try and negotiate. On 7 July 1904, Mary Howes and Blanche spoke to Mrs Leftley. Mary advised that the pregnancy had already proved costly and asked 'what they were going to do for me'. Mrs Leftley advised her that 'she would leave it to her husband'.$^{45}$ Shortly afterwards, Frederick Howes arranged a meeting with Harry and his father. Harry denied responsibility and Mr Leftley offered no financial recompense. In August 1904, Blanche herself confronted Harry and told him that if he did not do anything 'father is going to take it to Court'. Harry retorted that his father would spend 'every cent he had' defending the case. ${ }^{46}$

41 Statement of Edward Alfred Strahan, ibid.

42 Statement of Albert Anderson, ibid.

43 Statement of Victoria Ginn, $R v$ William Ginn, Melbourne Supreme Court, 10 December 1901, PROV, VPRS 30/P/0000, Unit 1274, Item 596.

44 Melbourne Supreme Court, 22 May 1905, PROV, VPRS 30/P/0000, Unit 1384, Item 135.

45 Statement of Mary Howes, ibid.

46 Statement of Blanche Howes, ibid. 
Despite this, the Howes family still apparently hoped for recompense even after the baby's birth in December 1904, for Frederick did not make a complaint to the police until April 1905. ${ }^{47}$

When a girl's father was dead, or he or a stepfather was the defendant, mothers usually stepped in, although a male family member or friend sometimes assisted them. In $R v$ Saddington, ${ }^{48}$ 15-year-old Florence Grumont and 18-year-old Hedley Saddington were fellow servants at a property near Mt Macedon. In January 1906, Florence complained to her widowed mother, Mary Grumont, that Hedley had sexually assaulted her four times between November and December 1905. Mary consulted William Donald, senior gardener at the house, for his views on the situation. Donald told her that if it was my child I would send for the police', but Mary was reluctant to do this, declaring that she '[didn't] want this thing made public' for the sake of Florence's reputation. Donald then arranged a meeting between himself, Hedley and Mary. Mary told Hedley she would not take the matter further if he '[w]ould keep his mouth closed in regard to the affair'. A few days later she reported the matter to the police because 'Saddington had been up reading reports about me and my daughter - I thought he ought to have kept silence [sic]'. ${ }^{49}$ In a rather different scenario, in $R v$ Upton ${ }^{50} 14$-yearold Gertrude Furzer was living with her widowed mother in a hotel in South Melbourne when she became involved with Herbert Upton, a married man with whom her brother was boarding. Their increasingly futile attempts to conceal the relationship finally ended when Gertrude became pregnant and her mother notified the police. Before that, Richard Alexander, barman at the hotel, had attempted to intervene with Herbert, telling him that 'he was a married man and should be ashamed of himself' ${ }^{51}$ Richard and several other neighbours gave evidence at the trial against Herbert.

Alexander might have assisted Mrs Furzer in remonstrating with Herbert and supporting her at trial, but it never seems to have occurred to him to go to the authorities himself. Such was the general respect for parental authority that other family members and friends rarely reported a suspected carnal knowledge case to the police except, again, where they stood in a parental capacity to the girls or, occasionally, when a mother failed to make a complaint against an offending father. Gravino, with the older sister's decisive intervention, was unusual. In $R v$ Mitchell, $^{52}$ Grace Frith, aged 12, was an orphan living with a foster family, who were effectively her employers, when she complained that the father of

\footnotetext{
47 Statement of Frederick Howes, ibid.

48 Melbourne Supreme Court, 15 February 1906, PROV, VPRS 30/P/0000, Unit 1414, Item 82.

49 Statements of Mary Grumont and William Donald, ibid. Hedley Saddington was acquitted, the Age noting that Florence was 'a hysterical character' whose 'evidence could not be relied upon', see 'Criminal Court', Age (Melbourne), 23 February 1906, 8.

50 Melbourne Supreme Court, 26 May 1905, PROV, VPRS 30/P/0000, Unit 1386, Item 178.

51 Statement of Richard Alexander, ibid.

52 Melbourne Supreme Court, 25 May 1903, PROV, VPRS 30/P/0000, Unit 1324, Item 217.
} 
the household had raped her. Her aunts reported the case to the police. ${ }^{53}$ In $R v$ Bower, ${ }^{54}$ Myrtle Bower, also 12, was living with her father and younger siblings in Footscray when her father sexually assaulted her. Myrtle's mother was dead, and she eventually told Alice Tischler, who had been employed for a time by her father to look after the children, that she had an unusual discharge. Having also seen Frank Bower behave suspiciously towards Myrtle one night when he came home drunk, Alice notified the police. ${ }^{55}$ Mothers who suspected their husbands of assaulting their daughters could find the decision to involve the authorities a very difficult one. Court transcripts indicated that they were often the victims of brutality themselves, as well as being financially dependent. In $R v$ Plozza, $^{56}$ Giacomo Bombardieri, uncle of 12-year-old Catterina Plozza, stepped in after his sister, Catterina's mother, refused to make a complaint against her husband, Giovanni Plozza. Catterina had told Giacomo that she had been assaulted, and Giacomo had himself tried to warn Giovanni off, without success. ${ }^{57}$

The same deference to parental prerogative also militated against girls making complaints personally. Once a girl involved her family members, her own decision-making power was severely restricted, as the family subsequently decided on the course of negotiations and if the offending would be reported to the police. This meant that some girls gave their evidence reluctantly and defiantly, emphasising the consensual nature of their relationships with the defendants. Kate Flynn, aged 17, had become involved with Edward Mackney, a married man and a family friend. On 12 October 1902 she ran away with him to Geelong, where they remained living together for a month until the police arrested her on a charge of vagrancy. Kate gave evidence of some pressure from Mackney to come away with him, but the escape itself was carefully planned - he paid for a new dress and gave her a wedding ring to wear - and she agreed to live with him in Geelong 'as his wife'.$^{58}$ On the few occasions when girls did notify the police themselves they either lacked this close network of relations and friends or had moved beyond the reach of parental control. In $R v$ Waterhouse, ${ }^{59}$ 13-year-old twins Hilda and Winifred Waterhouse complained to the police that their father, Henry, had raped them and made them perform oral sex on him, sometimes in front of each other, on multiple occasions over a three

\footnotetext{
53 Statement of Grace Frith, ibid.

54 Melbourne Supreme Court, 15 June 1903, PROV, VPRS 30/P/0000, Unit 1327, Item 287.

55 Statement of Alice Tischler, ibid.

56 Melbourne Supreme Court, 15 October 1901, PROV, VPRS 30/P/0000, Unit 1261, Item 400.

57 Statement of Giacomo Bombardieri, ibid.

$58 R v$ Mackney, Melbourne Supreme Court, 17 December 1902, PROV, VPRS 30/P/0000, Unit 1309, Item 563. As Kate was over 16, Mackney was charged with abduction of a girl under 18 from her parent with intent to carnally know. At the first trial he was convicted, but appealed. The issue at appeal was the relevance of Kate's consent, as the trial judge had directed that this was irrelevant. The appeal court held by majority that her 'willing participation' could be a defence to this charge, although not the ordinary carnal knowledge charge, and Mackney was subsequently acquitted by direction at a retrial. For the appeal decision, see $R v$ Mackney 19 Victorian Law Reports 1903, 22-28.

59 Melbourne Supreme Court, 15 July 1905, PROV, VPRS 30/P/0000, Unit 1393, Item 275.
} 
or four month period. The girls' mother had left the household for England in April 1904, and they lived with their father and older sister above their father's shop in Lonsdale Street, Melbourne. The girls reported the offending to police after they had been in service for several months, presumably gaining confidence from distance. ${ }^{60}$

Given this complex of family and community relationships that complainants and their families had to negotiate in the course of taking a matter to court, it was hardly surprising that reporting was frequently delayed and much debated. Although individual families' circumstances varied, there were common threads linking their final decisions to notify the police. Families tended to advise the authorities only after the offending became, to some extent, common knowledge and when alternative means of redress were either unavailable or had failed. A girl's pregnancy or suspected pregnancy was the frequent trigger for action. Not only did it alert family members to her sexual activity, but it meant that the wider community would inevitably become aware of it also. Further, for most of these households, it created immediate economic pressure about how to manage the coming baby. Such problems could be alleviated through marriage (if the girl was old enough) or financial assistance from the defendant and negotiations invariably focused on these points. In $R v$ Horton ${ }^{61}$ Elizabeth West discovered in December 1901 that she was pregnant to her boyfriend, William Horton. William was reluctant to marry her as he was already supporting his mother and sister. In early January 1902 he gave her money to buy 'medicine' in the hope of inducing an abortion, which failed. She then told her parents, who met with William on three occasions, pressuring him to marry her. On 28 January Elizabeth's father Ansell also paid a surprise visit to William at his workplace. On 1 February William eventually offered to pay Elizabeth's confinement expenses and a small ongoing allowance, but still refused marriage. Ansell said he 'would not hear of such a thing as that' and, on 4 February, he obtained a warrant for William's arrest. ${ }^{62}$

In some cases, of course, neither marriage nor financial assistance was an option. Where the father of a family was the offender, the economic crisis was of the opposite dimension, for if he was removed, his family could rapidly find themselves destitute. In September 1900, Emily Paul notified the police that her de facto husband, Thomas Paul, had sexually assaulted her 13-year-old daughter, Edith Richards. On 20 September Thomas Paul was committed for trial and remanded into custody. On 24 September Edith and her three younger half-siblings were committed to the Department for Neglected Children, Emily

60 Statements of Hilda Waterhouse, Winifred Waterhouse, and Sergeant Patrick McManamny, ibid. The jury disagreed in two trials and ultimately the prosecution decided not to proceed. The twins' older sister, Millicent, gave evidence against the girls.

61 Melbourne Supreme Court, 18 March 1902, PROV, VPRS 30/P/0000, Unit 1284, Item 168.

62 Statements of Elizabeth Ann West and Ansell Joseph West, ibid. 
declaring that 'she was entirely without means, and could not obtain any work' ${ }^{63}$ In such scenarios, mothers seem often to have reported husbands only when their relationship had already deteriorated, and an assault on a daughter was the final straw. ${ }^{64}$ In $R v$ Merry, ${ }^{65}$ for example, Cecilia and Thomas Merry had apparently had a volatile relationship for some years, Cecilia complaining that Thomas did not earn enough to keep her, forcing her to take in sewing, and Thomas that her daughters — his stepdaughters - were disrespectful. ${ }^{66}$ When Cecilia walked in on Thomas on top of her 15-year-old daughter, Beatrice Frazer, on Christmas morning 1903, she threw him out and took Beatrice to the police. ${ }^{67}$ Similarly, in $R v$ Dunkley, ${ }^{68}$ 14-year-old Elsie Jude was raped by her stepfather, Charles Dunkley, but was frightened to tell her mother because 'he [stepfather] was in the habit of hitting her [mother] and I thought he might murder her if I told her' ${ }^{69}$ When a neighbour advised Annie Dunkley of Elsie's allegations, she took Elsie to the police, later telling her husband that, 'I could forgive anything you've done to me but not to my daughter'.$^{70}$

\section{Expectations and outcomes}

Women like Cecilia Merry and Annie Dunkley reported assaults on their daughters in outrage and anger, presumably hoping that their husbands would be exposed and punished for their misdeeds. Desire for punishment was certainly one reason to bring offending to the attention of the authorities, but it was often only part, and sometimes a relatively minor part, of the overall decision. Economic considerations loomed large in pre-court negotiations, but most families do not seem to have expected that bringing the defendant to trial would itself lead to damages or any financial reward. Indeed, if the man or boy was convicted or imprisoned, they would not be able to claim any ongoing assistance from him at all for the life of the gaol term. This might explain why the Howes family held out for so long in $R v$ Leftley, waiting until well after the birth of the baby before reporting the case. Only when it became absolutely certain that Harry Leftley was not going to provide for their daughter did they finally notify the local police. On the other hand, some families did subsequently bring maintenance proceedings against a defendant, in which a conviction for

\footnotetext{
$63 R v$ Paul, Melbourne Supreme Court, 15 October 1900, PROV, VPRS 30/P/0000, Unit 1228, Item 414; 'Police Intelligence', Age (Melbourne), 25 September 1900, 5.

64 Louise Jackson comes to the same conclusion in her discussion of nineteenth-century Yorkshire and Middlesex cases, see Jackson, 47-48.

65 Melbourne Supreme Court, 15 February 1904, PROV, VPRS 30/P/0000, Unit 1346, Item 22.

66 Statements of Thomas Merry and Beatrice Frazer, ibid.

67 Statement of Beatrice Frazer, ibid.

68 Melbourne Supreme Court, 15 February 1903, PROV, VPRS 30/P/0000, Unit 1312, Item 9.

69 Statement of Elsie Jude, ibid.

70 Statement of Nellie Jude, ibid.
} 
carnal knowledge could be useful, indeed essential, evidence. Daniel Peddie, father of 14-year-old Marian Peddie, does not seem to have tried to negotiate with 17-year-old William Sievers when he discovered that he had impregnated his daughter. ${ }^{71}$ Nevertheless, on 17 September the North Melbourne Police Court made a maintenance order against William, noting that he had recently been convicted of 'intimacy' with Marian. ${ }^{72}$

More often, the threat of punishment was held over defendants' heads to try and force them to provide financial compensation or, in some cases, to stop the behaviour. Most of the witnesses in these cases were evidently aware that carnal knowledge of an underage girl was an offence punishable by a term of imprisonment. Mothers and fathers claimed repeatedly that they had warned young men that their daughters were under 16 and defendants sometimes made enquiries themselves. In $R v$ Weatherdon, ${ }^{73}$ Arthur Weatherdon asked the complainant, Josephine Barrett, with whom he had been 'walking out', how old she was. Josephine, an orphan, told him she thought she was 16, although she added that she had once been told that she was a year younger. Arthur was evidently satisfied with the first reply and persuaded her to come and live with him in furnished rooms. ${ }^{74}$ In $R v$ Watson, ${ }^{75}$ 15-year-old Eileen Fogg, also an orphan, lived with her aunt and uncle, Elizabeth and Joseph Morris, in the seaside town of Sorrento. In December 1905 Elizabeth Morris suspected that her niece might be pregnant and took her to the doctor, who confirmed that she was between five and six months pregnant. Eileen then disclosed that she had had a sexual relationship with three men, including James Watson. The Morrises duly attended on James and his mother, Joseph Morris advising James that 'it was not a simple case of maintenance [but] ... a criminal case and it might be very serious for him' if he did not co-operate. ${ }^{76}$ In a very different set of circumstances, when Giacomo Bombardieri told his brother-in-law Giovanni Plozza to stop assaulting his daughter, he also used the law as a backup, warning Plozza 'if you don't stop I will give you a summons' ${ }^{77}$

Above and beyond any desire for punishment or economic reward, however, a major expectation, reiterated again and again, was that a hearing would restore the reputation of a girl and her family in the eyes of the public. Involvement in extramarital sexual activity, whether it was consensual or not, exposed a girl, and by extension her relations, to community condemnation. There were frequent references throughout these cases to the shame that families experienced when

\footnotetext{
$71 R v$ Sievers, Melbourne Supreme Court, 17 August 1900, PROV, VPRS 30/P/0000, Unit 1224, Item 342.

72 'Police Intelligence', Age (Melbourne), 18 September 1900, 6.

73 Melbourne Supreme Court, 22 February 1900, PROV, VPRS 30/P/0000, Unit 1208, Item 96.

74 Statement of Elizabeth Barrett, ibid.

75 Melbourne Supreme Court, 23 February 1906, PROV, VPRS 30/P/0000, Unit 1411, Item 22.

76 Statement of Joseph Morris, ibid.

77 Statement of Giacomo Bombardieri, $R$ v Plozza.
} 
they became aware of their daughters' situation. These feelings did not vary noticeably even with very young children. We will recall in $R v$ Thomas Brown that Alice Anderson was reluctant to report a sexual assault on her very small girl 'for the child's sake'.$^{78}$ Girls who had been the subject of unwanted sexual advances felt the same humiliation. In $R v$ Francis Hendry, ${ }^{79}$ Bessie Martin had been raped by a family friend, a sailor who sometimes slept at their house. She told the Williamstown Police Court that, 'I never made a complaint as I did not want to disgrace them all' ${ }^{80}$ This sense of shame no doubt stopped many families from reporting incidents at all. For those who did, the trial was envisaged as a way to shift responsibility back onto the young man involved, by insisting that he was the dominant and/or coercive figure in the relationship. It also provided an opportunity for a family to assert (or re-assert) their own respectability. In both Leftley and $R v$ Sievers the parents emphasised that the sexual relationship had occurred in otherwise 'respectable' contexts. In Leftley, Blanche Howes's mother told the court that Harry Leftley had assaulted her daughter when she was 'coming home from business', and she was not otherwise allowed out at night. ${ }^{81}$

The twin aims of penalising the defendant, while exonerating the complainant and her family, were rarely achieved by the court process. Scholars like Jill Bavin-Mizzi and Constance Backhouse have emphasised the multiple legal and practical barriers young girls in carnal knowledge cases faced at all stages of the court process. These included the rules of evidence, which discriminated against uncorroborated evidence, the often offensively masculine atmosphere of the courtroom and the social attitudes, held by lawyers and magistrates alike, which assumed that sexually active young women, especially working-class girls, were morally untrustworthy. ${ }^{82}$ We have seen already that, overall, significantly less than half of the defendants in these cases were found guilty of the principal charge, although if guilty pleas and convictions for lesser charges are included, about 53 per cent of defendants were convicted of a charge. Breaking down the results in the Victorian cases between 1900 and 1906 supports the view that class, gender, and occasionally racial attitudes, significantly influenced outcomes at trial.

Carnal knowledge cases, as we have seen, usually involved working-class parties of the same social standing, hardly surprising when complainant and defendant were often either related or intimate acquaintances. In only eight cases out of the 68 was there a significant variation from this pattern. Two cases involved girls who might be described as either middle or lower middle class and working-class

78 Statement of Alice Anderson, $R v$ Thomas Brown.

79 Melbourne Supreme Court, 12 December 1906, PROV, VPRS 30/P/0000, Unit 1438, Item 495.

80 Statement of Elizabeth Martin, ibid.

81 Statement of Mary Howes, $R v$ Leftley.

82 Backhouse, 86-88, 107; Bavin-Mizzi, Ravished, 10-13. 
defendants. Catherine Bazeley was a baker's daughter from Leongatha whose father had employed the defendant as an apprentice. Lucy Hill was a farmer's daughter from Sorrento and the defendant was a labourer on the property. ${ }^{83}$ Generally, however, middle-class girls did not appear in this jurisdiction. In six other cases, the complainant was working class and the defendant middle or lower middle class. The typical social standing of the complainant created an immediate distance between the parties and magistrates or judges hearing the case, lawyers involved and possibly the jury members, for whom there was still a property qualification in this period. ${ }^{84}$

When the parties did not stand on an equal footing, the girl's class position does seem to have influenced the outcome of the trial. In all but one case when working-class girls brought charges against middle-class defendants they were unsuccessful, regardless of the strength of the evidence. In $R v$ Orr Margaret Green, a state ward, complained that she had been raped by her employer's son, William Orr. William made admissions to the police, but he was not convicted..$^{85}$ In $R v$ Whitley, ${ }^{86}$ 13-year-old Sarah Turner alleged that Charles Whitley, a teacher at the local state school, had sexually assaulted her whilst she was employed cleaning his home. When Sarah's mother took her to a local doctor he refused to examine her, not believing her complaint against a man in Charles's position. ${ }^{87}$ Although the prosecution produced a witness who had seen Charles entering the house at the relevant time, Sarah admitted under cross-examination that she had had a subsequent sexual relationship with another boy, which no doubt helped to further exonerate Charles. ${ }^{88}$ The one exception was Upton, discussed above, when there was an abundance of corroborating evidence linking working-class Gertrude Furzer with the middle-class (and married) Herbert Upton. Conversely, both the cases in which girls made complaints against a man of lesser social standing ended in convictions. In $R v$ McPherson, for example, 12-year-old Catherine Bazeley was sexually assaulted by, and became pregnant to, Neil McPherson, her father's employee who had lived with them. Catherine said nothing about the incident until her mother noticed her pregnancy five months later, and both parents admitted that they had not observed anything at the time. ${ }^{89}$ These might have been damning factors in other cases, but Neil was convicted.

Whether parties came from urban or rural areas had a noticeable effect on the statistics. A significantly higher percentage of matters from rural areas ended in

$83 R v$ McPherson, 16 September 1901, Melbourne Supreme Court, PROV, VPRS 30/P/0000, Unit 1264, Item 433 and $R v$ Swift, Melbourne Supreme Court, 15 October 1902, Unit 1305, Item 503.

84 Juries Act 1890 (Vic), s 5.

85 Statement of Margaret May Green, $R v$ Orr.

86 Melbourne Supreme Court, 15 July 1901, PROV, VPRS 30/P/0000, Unit 1251, Item 243.

87 Statement of Sarah Turner senior, ibid.

88 Statement of Sarah Turner junior, ibid.

89 Statement of Catherine Mary Bazeley, $R v$ McPherson. 
acquittal than the average across all regions ( 16 out of 24 , or 66.6 per cent). One rural defendant pleaded guilty to the principal charge and one pleaded guilty to a lesser charge, so only five were convicted after trial ( 21 per cent). It would require further study to see whether this was a general pattern or representative only of this relatively small number of subject cases. The types of negotiations were not especially distinctive in the rural transcripts, and we cannot know how many assaults were in fact reported, or how many did not progress past the committal stage. Nevertheless, there are some possible explanations for the differential outcomes in rural matters. Four of the six cases which involved working-class girls and defendants of higher social standing were from rural areas, all of them unsuccessful. Three of the rural cases from 1906 involved the same complainant, Eileen Fogg, who as we shall see below was discredited as a witness because of her relationship with multiple men. In her study of South Australian state wards, Margaret Barbalet has suggested that sexual assault may have been more prevalent in country areas, in part because girls were more isolated..$^{90}$ The Victorian cases would not necessarily suggest that sexual assault was more common in the country, but isolation could certainly make a case more difficult to prove, through the absence of corroborating witnesses. Certainly, in at least five of the unsuccessful cases, there was clear evidence of sexual penetration but no evidence beyond the girl's statement identifying the man responsible..$^{91}$

Race or ethnicity was less often a consideration in these trials, as both complainants and defendants were mostly white and English speaking. In three of these cases, however, the defendant's background was not British (or Irish) and this was clearly a factor at trial. Witness statements and investigatory reports indicated that the police and the courts approached these matters differently, and they all ended in conviction. In Plozza, the Plozza family were recent Italian migrants and both the investigating officer and jury evidently viewed the whole family as 'less civilised'. When Giovanni Plozza was convicted of incest, the jury recommended mercy 'on account of his being a foreigner and probably ignorant of the law' ${ }^{92}$ The same assumptions seem to have been at work in $R v$ Keefe. ${ }^{93}$ Isaac Keefe, an Aboriginal boy from Coranderrk station near Healesville, was accused of assaulting seven-year-old Emma Patterson, a 'half caste'.$^{94}$ Unusually, Isaac's first trial was suspended so that he could be legally represented, but

\footnotetext{
90 Margaret Barbalet, Far From a Low Gutter Girl: The Forgotten World of State Wards, South Australia 1887-1940 (Melbourne: Oxford University Press, 1983), 90-91.

$91 R v$ Carlsen, Melbourne Supreme Court, 15 February 1900, PROV, VPRS 30/P/0000, Unit 1208, Item 93; $R v$ Lamb, Melbourne Supreme Court, 15 February 1901, Unit 1241, Item 66; $R v$ Cummings, Melbourne Supreme Court, 15 August 1902, Unit 1298, Item 393; $R v$ Hyle, Melbourne Supreme Court, 15 April 1904, Unit 1352, Item 117; R v Manverton, Melbourne Supreme Court, 16 May 1904, Unit 1357, Item 230.

$92 R v$ Plozza, notation on brief.

$93 R v$ Keefe, Melbourne Supreme Court, 10 December 1902, PROV, VPRS 30/P/0000, Unit 1309, Item 568.

94 Statement of Constable William Henry Hocking, ibid.
} 
his guilt was assumed from the outset and he duly confessed, so the trial was a formality only. In $R v$ Abdulla $h^{95}$ members of a local working-class family pitted themselves against the defendant, Chaudri Abdullah, variously described as 'Indian' or 'Hindoo'. Fifteen-year-old Blanche Blight complained that Chaudri, her brother-in-law, had raped her. Blanche's older sister Miriam had married Chaudri's older brother Miyan Abdullah without the consent of their father, James, and the assault took place at Miyan's shirt factory where Blanche worked. The relationship, and Miyan's superior financial circumstances, evidently rankled James Blight immensely and he could barely contain his wrath at having to let Blanche work in an environment 'full of Indians and Hindoos' ${ }^{96}$ The jury perhaps sympathised for, despite much debate about a possible alibi, Chaudri was eventually convicted of carnally knowing Blanche.

Of course, whatever the class or ethnic background of complainant and defendant, a girl's reputation still remained relevant. As in rape trials, sexual knowledge was a weapon and, while the prosecution might enquire about a defendant's situation, they were far more interested in that of the girl and her immediate family. In such circumstances, Ruby Lever's case against Samuel Pimlott was doomed from the outset. Fifteen-year-old Ruby was living with her widowed mother, Christina Lever, in a notorious slum area of Fitzroy when she complained that Samuel Pimlott, a friend (and, possibly, client) of her mother's, had forced his way into her room and raped her. At trial Samuel gave evidence that 'it was an immoral house and I thought Mrs Lever was a prostitute', although he conceded that Ruby did not have an immoral reputation. ${ }^{97}$ Samuel was acquitted. Even without such associations, girls were habitually crossexamined at length on their interactions with other boys; whether they worked in mixed workplaces or went out at night and any prior sexual history. Even young children were not immune from this line of questioning. Sarah Barber was nine years old when she was raped by her uncle, Charles Thompson. The Crown Solicitor's Office demanded extra information from the police about Sarah's school attendance, 'truthfulness' and whether she was allowed out on the streets. ${ }^{98}$ Consent was not a defence in carnal knowledge cases, unless the defendant was younger than the complainant, and relations with others were also legally irrelevant, but both were recognised means of obtaining jury and judicial sympathy for defendants. Eileen Fogg, from Sorrento, confessed

$95 R v$ Abdullah, Melbourne Supreme Court, 15 August 1900, PROV, VPRS 30/P/0000, Unit 1223, Item 326.

96 Statement of James Blight, ibid.

$97 R$ v Pimlott, Melbourne Supreme Court, 22 May 1900, PROV, VPRS 30/P/0000, Unit 1216, Item 215.

98 Police Queries and Answers, $R v$ Thompson, Melbourne Supreme Court, 18 October 1904, PROV, VPRS 30/P/0000, Unit 1367, Item 393. 
to sexual relations with three boys. Her aunt Elizabeth Morris subsequently brought action against all three but, despite admissions confirming Eileen's version of events, they were all acquitted. ${ }^{99}$

\section{Conclusion: Using the law}

Carnal knowledge cases that were heard in the Melbourne Supreme Court between 1900 and 1906 were familiar affairs. The vast majority of complainants knew the defendants, often intimately, and court proceedings took place amidst a complex network of family and community relationships. In many of these cases, law functioned as a secondary mechanism for regulating sexual relationships. Most families understood by 1900 that carnal knowledge was a crime and that they had the right to prosecute. The decision to engage with the judicial system, however, frequently came only after private negotiations had failed, or where settlements were impossible in the circumstances of a particular case. Negotiations reflected gender and power balances within families and communities. Fathers or male family members customarily initiated legal proceedings, with women taking charge only if men were unavailable. Respect for parental or familial authority was such that young women outside the protection of a family were significantly less likely to report, or have their case taken up by others, including state agents. Girls themselves rarely had the influence, or courage, to take such a step independently. Once other family members had become involved, decision-making power no longer rested with the young woman concerned, although she might continue to play a role in discussions. The decision to prosecute was much more likely if complainant and defendant stood on an equal social footing. When the defendant was of a higher social class, both reporting and conviction were significantly less likely. It was also, overwhelmingly, a white working-class jurisdiction. Middle-class girls appeared in only two cases and ethnic minorities also very rarely.

When working-class families and their friends did report carnal knowledge cases to the police, they apparently did so on the expectation that a trial would punish a defendant and restore respectability to the girl and her family. These expectations revealed the limits of their understanding of the legal system, for even when a hearing led to the defendant's conviction, it did not usually salvage the reputation of either the young complainant or her associates. Girls' moral characters were examined in far greater detail than those of defendants, invariably to their detriment. When exploring the regulation of sexual conduct, we are nevertheless reminded repeatedly that these people were not simply the

$99 R v$ Skelton, Melbourne Supreme Court, 23 February 1906, PROV, VPRS 30/P/0000, Unit 1412, Item 33; $R$ $v$ Watson, Melbourne Supreme Court, 23 February 1906, Unit 1411, Item 22; $R v$ Hibbert, Melbourne Supreme Court, 23 February 1906, Unit 1412, Item 34. 
subjects of intervention. In the majority of cases, discretion to prosecute rested with family members rather than state agents. At most points in the process, working-class families, if not young girls themselves, retained a large degree of agency and their choices to use the law were based upon social and moral, rather than legal, imperatives. Transcripts of carnal knowledge cases allow us to listen to the voices of working-class communities at the turn of the twentieth century 'in their own words', with all their emotion, anxiety and distress. By listening to these voices, we can track attitudes to gender, class, sexuality and morality as they played out in everyday life and in the legal system. We can also chart the reach of the regulatory state, by unpicking the complex dynamics informing crucial decisions to make the private public, or by engaging with the legal system in the first place. 